\title{
REVOLUTIONARIES BEWARE: THE EROSION OF THE POLITICAL OFFENSE EXCEPTION UNDER THE 1986 UNITED STATES-UNITED KINGDOM SUPPLEMENTARY EXTRADITION TREATY
}

\section{John Patrick Groarke†}

In response to increasing terrorist activity against Western democratic countries, the United States has begun to amend its extradition ${ }^{1}$ treaties with such countries in order to facilitate the return and punishment of fugitive terrorists. ${ }^{2}$

The first extradition treaty to be so altered is the one between the United States and the United Kingdom. ${ }^{3}$ This treaty was chosen because of three recent United States court decisions ${ }^{4}$ that barred the return of suspected Provisional Irish Republican Army ("PIRA") terrorists to the United Kingdom for trial. ${ }^{5}$ The courts denied the extradition requests because they believed the acts committed by the fugitive terrorists were "political" in nature, and therefore subject to the political offense exception of article 5 of the United States-United Kingdom Treaty of Extradition. ${ }^{8}$ It is this political offense exception

† B.A. 1980, New York University; M.Sc. 1984, The London School of Economics and Political Science; Lecturer in Public International Law 1984-85, The Polytechnic of North London; J.D. Candidate 1988, University of Pennsylvania.

1 The Supreme Court has defined extradition as "the surrender by one nation to another of an individual accused or convicted of an offense outside of its own territory, and within the territorial jurisdiction of the other, which, being competent to try and to punish him, demands [his] surrender." Terlinden v. Ames, 184 U.S. 270, 289 (1902).

${ }^{2}$ See United States and United Kingdom Supplementary Extradition Treaty: Hearings on Treaty Doc. 99-8 Before the Senate Comm. on Foreign Relations, 99th Cong., 1st Sess. 2 (1985) [hereinafter Hearings] (statement of Judge Abraham Sofaer, Legal Adviser, U.S. Department of State).

3 Extradition Treaty, June 8, 1972, United States-United Kingdom, 28 U.S.T. 227, T.I.A.S. No. 8468 [hereinafter 1972 Treaty].

In re Mackin, 668 F.2d 122 (2d Cir. 1981); In re Doherty, 599 F. Supp. 270 (S.D.N.Y. 1984); In re McMullen, Mag. No. 3-78-1099 (N.D. Cal. May 11, 1979), reprinted in 132 Cong. Rec. $S 9146$ (daily ed. July 16, 1986).

- See Hearings, supra note 2, at 5 (statement of Judge Abraham Sofaer).

- 1972 Treaty, supra note 3, art. 5, II (1)(c)(i), at 920.6; see Mackin, 668 F.2d at 137 (concluding that a magistrate had jurisdiction to decide the political offense question, and that her decision that the offenses for which extradition was sought came within the political offense exception was not appealable); Doherty, 599 F. Supp. at 276 ("T T] $]$ he facts of this case present the assertion of the political offense exception in its most classic form."); McMullen, mag. No. 3-78-1099 (N.D. Cal. May 11, 1979) ("We find that the defendant has established . . . that the act of bombing the Claro Barracks was political in character."). 
that has been redefined in the Supplementary Treaty entered into by the United States and the United Kingdom. ${ }^{7}$

The new Supplementary Treaty no longer permits United States judges to decide that a fugitive's violent acts constitute a political crime and therefore immunize the fugitive from extradition. ${ }^{8}$ In its place, the Supplementary Treaty provides that all fugitives accused of committing violent acts can be extradited even if their acts were politically motivated. $^{\circ}$ The Supplementary Treaty does, however, allow a court to deny extradition if it finds by a preponderance of the evidence that the requesting state cannot provide the fugitive with a fair trial. ${ }^{\mathbf{1 0}}$

This Comment examines how the Supplementary Treaty affects the extraditability of PIRA fugitives in the United States, and whether or not there should be further treaties between the United States and its allies. The problems federal judges will face in determining the fairness of the trial a fugitive will receive if extradited will also be examined.

This Comment asserts that although the Supplementary Treaty will be effective in preventing alleged PIRA terrorists from gaining refuge in the United States, it still fails to balance adequately an alleged terrorist's right to a fair trial against a democratic government's need to protect itself against terrorism. It submits that a better way to deal with this problem would be to establish a special court under the supervision of a third party, the European Community, in order that alleged terrorists may be tried in a more impartial atmosphere.

\section{BAckground to the Supplementary Treaty}

\section{A. Extradition in American Law}

Extradition is as old as international relations. The 1280 B.C. peace treaty between Ramses II of Egypt and the Hittite King Hattusili III, the second oldest known document in diplomatic history, contained a provision calling for the return of criminals from one country found in the territory of the other. ${ }^{11}$ It was not until the eighteenth century, however, that international cooperation in the extradition of criminals assumed its present character. ${ }^{12}$

7 Supplementary Extradition Treaty, June 25, 1985, United States-United Kingdom, S. EXec. ReP. No. 17, 99th Cong., 2d Sess. 15 (1985), reprinted in 24 INT'L Legal Materials 1105-1109 (1985) [hereinafter Supplementary Treaty].

${ }^{8}$ See infra note 29 and accompanying text.

8 Supplementary Treaty, supra note 7 , art. 1 .

10 Id., art. 3.

11 See M. Bassiouni, International Extradition: United States Law AND PRACTICE $\S 1.6$ (1987).

12 See I. Shearer, Extradition in International Law 5 (1971). For a de- 
The first extradition treaty entered into by the United States or, for that matter, by the United Kingdom, was the Jay Treaty of $1794 .^{13}$ This treaty established the framework for all future United StatesUnited Kingdom extradition treaties. ${ }^{14}$ It provided for the return of fugitives who had committed offenses listed within the treaty. ${ }^{18}$ The requesting state could only make a demand for a fugitive who had committed a treaty offense and had to present at least a prima facie showing that the person sought had committed such an offense. ${ }^{18}$

The list of extraditable offenses was expanded in the next AngloAmerican extradition treaty, the Webster-Ashburton Treaty of $1842 .{ }^{17}$ Subsequent additions to the list were made through supplementary treaties signed in 1889,1900 , and $1905 .^{18}$ The 1972 treaty lists twentynine extraditable offenses. ${ }^{10}$

There is no United States statute that deals explicitly with the substance of extradition law. ${ }^{20}$ Rather, the substantive law is codified in the ninety-six extradition treaties the United States has with other countries. ${ }^{21}$ Extradition procedures are, however, governed by statute ${ }^{22}$ and apply to all requests for fugitives in the United States. ${ }^{23}$

In brief, 18 U.S.C. $\S 3184$ provides that after a requesting state has made a demand for a fugitive, any federal magistrate or judge may hold a hearing to consider the sufficiency of the evidence to sustain the criminal charge under the treaty being used to authorize extradition. If

tailed discussion of eighteenth and early nineteenth century American extradition practice, see Evans, Legal Bases of Extradition in the United States, 16 N.Y.L.F. 525 (1970).

13 Jay Treaty, Nov. 19, 1794, United States-Great Britain, 8 Stat. 116, T.S. No. 105 [hereinafter Jay Treaty]; see I. Shearer, supra note 12, at 12-13.

14 See I. Shearer, supra note 12 , at 13.

16 See Jay Treaty, supra note 13, at 2 (the treaty offenses included forgery and murder); I. SHEARER, supra note 12, at 13.

16 See I. Shearer, supra note 12, at 13.

17 Webster-Ashburton Treaty, Aug. 9, 1842, United States-Great Britain, 8 Stat. 572, T.S. No. 119 (expanded list of offenses included arson, piracy, robbery, and assault with intent to commit murder).

${ }^{18}$ See I. Shearer, supra note 12, at 14 n.5. (noting that the 1889 treaty prevented the extradition of political offenders).

191972 Treaty, supra note 3, art. III \& annexed schedule.

${ }^{20}$ See Banoff \& Pyle, "To Surrender Political Offenders": The Political Offense Exception to Extradition in United States Law, 16 N.Y.U. J. INT'L L. \& PoL. 169, 175 (1984) ("Although the United States has made up for its tardy acceptance of extradition by negotiating almost one hundred bilateral treaties, it has not yet enacted its own substantive statute." (footnotes omitted)).

2118 U.S.C. $\S 3181$ (1982).

${ }^{22} I d$. $\S 3184$.

${ }^{23} I d$. 
the evidence is found sufficient, the executive branch can choose whether or not to return the fugitive. ${ }^{24}$

There are several important restrictions on a federal court's power to authorize extradition. First, there must be an extradition treaty in force between the United States and the requesting state. ${ }^{25}$ Second, the crime the fugitive is accused of committing must be listed in the treaty. ${ }^{28}$ Next, the crime of which the fugitive is accused must be a criminal offense in both countries; this principle is usually known as "double criminality." ${ }^{\text {"2n }}$ Moreover, the requesting state can only try an extradited fugitive for the crime for which she was extradited. This is known as the "specialty" principle. ${ }^{28}$ Finally, a fugitive cannot be extradited if her crime was "political" in nature. This is known as the "political offense" exception and it is the major issue addressed in the Supplementary Treaty. ${ }^{29}$

\section{B. The Political Offense Exception}

There is no current universally accepted definition of a "political

24 See 18 U.S.C. $\S 3186$ (1982) ("The Secretary of State may order the person committed under sections 3184 or 3185 of this title to be delivered to any authorized agent of such foreign government, to be tried for the offense of which charged." (emphasis added)); Banoff \& Pyle, supra note 20, at 175-76.

25 18 U.S.C. § 3181 (1982); see Banoff \& Pyle, supra note 20 , at 176 . It has been asserted that the basis for this policy is a concern for the rights of the accused to due process and a suspicion of foreign criminal law processes. See Evans, supra note 12, at 525-26; see also Banoff \& Pyle, supra note 20, at 176 ("In contrast [to the U.S.], other nations will extradite as a matter of comity, even if no treaty or convention exists with the requesting state.").

${ }^{28}$ See United States v. Rauscher, 119 U.S. 407, 430 (1886) ("[A] person who has been brought within the jurisdiction of the court by virtue of proceedings under an extradition treaty, can only be tried for one of the offences described in that treaty . . . .); 6 M. Whiteman, Digest of INTERnational Law 732-33, 772 (1968); Banoff \& Pyle, supra note 20, at 176-77; see also 18 U.S.C. $\$ 3184$ (1982) (A fugitive suspect can be certified for extradition only if the fugitive is charged with committing "any of the crimes provided for by [the] treaty or convention.").

${ }^{27}$ See Collins v. Loisel, 259 U.S. 309, 311 (1922) ("[A]n offense is extraditable only if the acts charged are criminal by the laws of both countries."); Kelley v. Griffin, 241 U.S. 6 (1916) (same); Wright v. Henkel, 190 U.S. 40, 60-61 (1903) (same); Banoff \& Pyle, supra note 20 , at 177 ("This double criminality standard is widely accepted in international extradition practice, but poses some problems when applied in the context of a federal system which leaves the task of defining most crimes to state legislators.").

${ }^{28}$ See Johnson v. Browne, 205 U.S. 309, 321 (1907) (holding that a treaty should not be used to "obtain the extradition of a person for one offense and then punish him for another and different offense"); M. BAssiounI, INTERNATIONAL EXTRADITION AND World PuBlic ORder 352-60 (1974) [hereinafter M.Bassiouni, InTERnATIONAL ExTRADITION] (providing a thorough discussion of the "specialty" principle); Banoff \& Pyle, supra note 20, at 177.

${ }^{29}$ See Supplementary Treaty, supra note 7 , art. 1. 
offense."30 Consequently, states have different views as to the scope of the exception. ${ }^{31}$ What is clear is that most states will not extradite a fugitive who has committed a "political" offense. ${ }^{32}$

There are three basic policy reasons behind the political offense exception..$^{33}$ One is a humanitarian concern for the individual being sought. The exception protects the individual from an unfair or retaliatory trial by the requesting state, which, being the target of the alleged offense, will function as both judge and jury. ${ }^{34}$ Another reason for having the exception is that if such offenses were extraditable, the asylum state could become involved in an internal political dispute in the requesting state and therefore be seen as "taking sides" in the dispute. ${ }^{35}$ Neutrality is important to the asylum state because today's political offenders could become tomorrow's political leaders. ${ }^{36}$ A blanket policy of nonextradition for political offenders best ensures the asylum state's neutrality. ${ }^{37}$

A final reason for having a political offense exception is that the international community tends to view political offenses as less "anti-

so See Banoff \& Pyle, supra note 20, at 177-78; Gilbert, Terrorism and the Political Offence Exemption Reappraised, 34 INT'L \& CoMP. L.Q. 695, 695 (1985) (suggesting that the judiciary's attempts to determine whether "terrorist" acts fall within the political offense exception may simply mask courts' otherwise overtly political decisions); Lubet, Extradition Reform: Executive Discretion and Judicial Participation in the Extradition of Political Terrorists, 15 CORNELL INT'L L.J. 247, 253 (1982) (arguing that the originators of the political offense exception deliberately left term "political offense" undefined in order to keep its scope broad); Note, American Courts and Modern Terrorism: The Politics of Extradition, 13 N.Y.U. J. INT'L L. \& PoL. 617, 61719 (1981) ("[N]o attempt has been made to define 'political offense' . . . .").

${ }^{31}$ For a discussion of the different positions adopted by various states, see GarciaMora, The Nature of Political Offenses: A Knotty Problem of Extradition Law, 48 VA. L. REv. 1226, 1240-56 (1962); Gilbert, supra note 30, at 697-702.

${ }^{32}$ See Lubet, supra note 30, at 251-52 (the exception is so universal that there is an international "norm of]] political asylum").

${ }_{33}$ See S. Bedi, Extradition in International Law and Practice 180-81 (1966) ("II]f the individual had a right to revolt against tyranny, those who failed . . . should be granted asylum in the countries to which they had fled."); Banoff \& Pyle, supra note 20, at 180-81; Gilbert, supra note 30, at 695 (Political exemption allowed the asylum state to remain disinterested in the internal affairs of other sovereign states.).

34 See C. Van den Wijngaert, The Political Offense Exception to ExTRADITION 3 (1980).

3s See Banoff \& Pyle, supra note 20, at 181; Gilbert, supra note 30, at 695.

${ }^{36}$ See Banoff \& Pyle, supra note 20 , at $180-81$.

s7 See id. at 174 (discussing the effects of extradition on international tensions); Cantrell, The Political Offense Exemption in International Extradition: A Comparison of the United States, Great Britain and the Republic of Ireland, 60 MARQ. L. REv. 777, 782 (1977) (Justifications for refusal to extradite are "bolstered by an unwillingness to become entangled in the requesting state's internal affairs."); Note, supra note 30, at 622 ("By exempting all political offenders from extradition, a nation may also achieve the desirable goal of avoiding entanglement in the internal political affairs of other states."). 
social" than ordinary criminal offenses. Indeed, a political offender often is considered to be a hero. For example, the United States has long considered revolutionaries struggling against totalitarian governments to be heroes. ${ }^{38}$

There are generally two types of political offenses: pure and relative. Pure political offenses are those that are subversive toward a particular government or its leaders. Typical examples of pure political crimes include treason, espionage and sedition. ${ }^{39}$ Since such acts are usually not treaty offenses, they are not ordinarily extraditable crimes. $^{40}$

Relative political offenses involve the commission of common crimes in connection with a political act or event. ${ }^{41}$ When the common crime is a treaty offense, the courts must decide if it falls on the political side of the line and thus becomes subject to the political offense exception. ${ }^{42}$

Belgium was the first state to formalize the concept of the political offense when it was codified in its extradition law of 1 October 1833.43 The exception was included in an extradition treaty concluded between Belgium and France in 1834. ${ }^{44}$ The first United States extradition treaty to contain the political offense exception was the one it concluded with France in $1843 . .^{45}$ The political offense exception is currently a part of all United States extradition treaties. ${ }^{46}$

${ }^{38}$ See S. BEDI, supra note 33, at 180-81 (political offenders were sometimes seen as heroes during the mid-nineteenth century); Banoff \& Pyle, supra note 20, at 180 ("Political offenders [are sometimes regarded] as fighting against tyrannical governments.").

${ }_{39}$ See Banoff \& Pyle, supra note 20, at 178; Note, supra note 30, at 623-24.

10 See Banoff \& Pyle, supra note 20 , at 178 .

1 See id.; Note, supra note 30, at 624. For a further discussion of pure and relative political offenses, see Bassiouni, Ideologically Motivated Offenses and the Political Offenses Exception in Extradition-A Proposed Juridical Standard for an Unruly Problem, 19 DE Paul L. REv. 217, 245-254 (1969); Cantrell, supra note 37, at 780-82; Garcia-Mora, supra note 31, at 1239; Note, The Political Offense Exception to Extradition: A 19th Century British Standard in 20th Century American Courts, 59 Notre Dame L. Rev. 1005, 1009 (1984).

${ }^{42}$ See I. Shearer, supra note 12, at 169 (describing English court interpretations); see also In re Doherty, 599 F. Supp. 270, 276 (S.D.N.Y. 1984) ("[I]t is proper for the Court to consider the nature of an organization, its structure, and its mode of internal discipline, in deciding whether the act of its members can constitute political conduct under an appropriate interpretation of the Treaty.").

${ }^{43}$ See I. Shearer, supra note 12 , at 167 ; Note, supra note 30 , at 620 . At least one prominent international jurist has asserted that Belgium enacted the law to protect fugitives because it had successfully revolted against the Netherlands in 1830 . See $1 \mathrm{~L}$. OPPENHEIM, INTERNATIONAL LAw 645 (H. Lauterpacht 8th ed. 1955).

"See I. SHEARER, supra note 12, at 167; Gilbert, supra note 30, at 696.

45 See I. SheARer, supra note 12 , at 167.

16 See Lubet, supra note 30, at 250; Note, Eliminating the Political Offense Exception for Violent Crimes: The Proposed United States-United Kingdom Supplemen- 
Generally, there have been three different approaches to defining the scope of the political offense exception. ${ }^{47}$ One approach, the socalled "injured rights" test, has been developed by the French courts. As enunciated in the 1947 case of In re Giovanni Gatti, ${ }^{48}$ the injured rights test includes among "political offenses" only those offenses that directly threaten the state. In Giovanni Gatti, France granted the extradition request of the Republic of San Marino for one of its nationals who tried to kill a member of a communist cell. ${ }^{48}$ In its opinion, the French Court of Appeals distinguished political crimes from common crimes:

In brief, what distinguishes the political crime from the common crime is the fact that the former only affects the political organisation of the state, the proper rights of the state, while the latter exclusively affects rights other than those of the state. The fact that the reasons of sentiment which prompted the offender to commit the offense belong to the realm of politics does not itself create a political offense. ${ }^{50}$

The major utility of this test is that it prevents a fugitive from using a possible political motivation to escape punishment for an otherwise common crime. ${ }^{51}$ This rather narrow definition, however, still excludes those political offenders who sincerely want political change but whose actions do not affect the state directly. ${ }^{\mathbf{6 2}}$

Another well developed approach is the Swiss "political motiva-

tary Extradition Treaty, 26 VA. J. INT'L L. 755, 759 (1986); see also 18 U.S.C. $\S 3181$ (1982 \& Supp. IV 1986) (listing countries with which the United States has extradition treaties).

47 See Note, supra note 30, at 624-32; Note, supra note 41, at 1009-11; see also Gilbert, supra note 30, at 697 (Gilbert divides one of the approaches so he concludes that there are actually four separate approaches).

48 S. Jur. II 44 (Cours d'appel, Grenoble 1947), 14 Ann. Dig. 145 (Ct. App. Grenoble, Fr. 1947).

${ }^{48}$ Id. at 44, 14 Ann. Dig. at 145; see also Gilbert, supra note 30, at 700 ("This is a very strict interpretation of the exemption, only conferring asylum on those offenders whose crimes affected the State alone and in no way harmed individuals-espionage, sedition or lèse majesté would fall within the test, but not murder of the Head of State with the aim of seizing power.").

so S. Jur. II at 45, 14 Ann. Dig. at 145.

51 See Note, supra note 30, at 629-30. For a survey of the most recent French applications of the doctrine see Carbonneau, The Political Offense Exception as Applied in French Cases Dealing with the Extradition of Terrorists: The Quest for an Appropriate Doctrinal Analysis Revisted, in Transnational Aspects of Criminal Procedure 209 (Mich. Y.B. INT'L Legal Stud. 1983).

${ }^{52}$ For example, a person who planted an explosive in front of a government building would not pass this test despite her political motivation if, in fact, the explosive injured innocent bystanders. 
tion" test. ${ }^{53}$ This test balances the political and common elements of the crime. Only if the political element dominates is the fugitive not extraditable. $^{54}$ The balancing test was explained in the Swiss case of In re Nappi:

[T] he political character of an offence is predominant only if the offence is in direct relation to the end sought. In order that such a relation may exist, the offence must be a really efficacious method of achieving the end, or constitute an integral part of acts leading thereto, or represent an incident in a general political movement in which the parties have recourse to such methods. ${ }^{58}$

The British and American Courts have not followed the French or Swiss but instead have developed their own test, the so-called "political incidence" test. ${ }^{57}$ This test was first employed by the British House of Lords in the case of In re Castioni. ${ }^{58}$ The fugitive being sought in that case was a Swiss national who had fled to England after leading an attack on a local cantonal government. During the attack, Castioni allegedly killed a member of that government. ${ }^{69}$ The Swiss request for his extradition was denied by the British court because the Lords found that Castioni's actions were political. ${ }^{60}$ They stated the relevant test as being "whether, upon the facts, it is clear that the man was acting as one of a number of persons engaged in acts of violence of a political character with a political object, and as part of the political movement and rising in which he was taking part."

[I] $\mathrm{t}$ must at least be shewn that the act is done in furtherance

ss See Gilbert, supra note 30, at 701 (noting that "the Swiss approach is the most developed . . . and is widely accepted by academic writers"); Note, supra note 30 , at 630.

s4 See Gilbert, supra note 30, at 701-02 ("If the crime is violent then the common element will outweigh the political motive unless such violence is the only means of achieving the end."); Note, supra note 30 , at $630-31$ (the test is met only if "the political objective predominate[s] over the common crime"); Note, supra note 41, at 1011 (The Swiss test's "flexible mechanism for balancing objective and subjective factors is uniquely tailored to assist courts in assessing relative political acts.").

ss 78 ATF 123 (Tribunal fédêral 1952), 19 I.L.R. 375 (Switz. Fed. Tribunal 1952).

${ }^{s 6} I d$. at 376.

${ }^{57}$ See In re Doherty, 599 F. Supp. 270, 274-75 (S.D.N.Y. 1984); Banoff \& Pyle, supra note 20, at 183-88 (also referring to this test as "the uprising test."); Gilbert, supra note 30, at 697-98; Lubet, supra note 30, at 261-66; Note, supra note 30, at 624-29.

s8 [1891] 1 Q.B. 149 (1890).

58 Id. at 150 .

${ }^{60} \mathrm{Id}$. at 159.

61 Id. 
of, done with the intention of assistance, as a sort of overt act in the course of acting in a political matter, a political rising, or a dispute between two parties in the State as to which is to have the government in its hands ... . ${ }^{62}$

The Court thus established a two-part test. This test requires that (1) the act be committed during an uprising, including a group of which the accused is a member, and (2) that the act be one of political violence committed by the accused for a political end. ${ }^{63}$ The political end was later defined as the furtherance of a conflict between different parties contending for power in a state. ${ }^{64}$

United States courts first adopted the Castioni political incidence test in the 1894 case of In re Ezeta. ${ }^{65}$ The accused, Ezeta, had disposed of the Salvadorian government before he was overthrown in a subsequent revolution. The new government wanted to try him on charges of murder and robbery. The American court refused to extradite him on the grounds that Ezeta's acts brought him under the protection of the political offense exception. ${ }^{86}$ The court's conclusion, arrived at through a mechanical application of the Castioni test, was inevitable, as Ezeta's acts took place incidental to a violent insurrection. ${ }^{67}$

American courts continued to apply the Castioni test rigidly, regardless of the reasonableness of the result. ${ }^{68}$ For example, in United States ex rel. Karadzole v. Artukovic, ${ }^{69}$ the district court blocked the extradition of a Yugoslavian war criminal because the mass murder he was accused of committing occurred during, and in furtherance of, an armed struggle between Serbs and Croats in pro-Nazi Croatia. ${ }^{\mathbf{7 0}}$ Critics have argued that war criminals should not be protected by the exception no matter how "political" their acts. ${ }^{71}$

${ }^{62} I d$. at 156.

${ }^{63}$ Id.; see Note, supra note 30, at 625.

o4 See In re Meunier, [1894] 2 Q.B. 415, 419 (Cave, J.).

es 62 F. 972, 995-99 (N.D. Cal. 1894); see Banoff \& Pyle, supra note 20, at 18384 (political incidence test first adopted by American courts in Ezeta shortly after Castioni decision); Note, supra note 30 , at 625 \& n.50 (same).

${ }_{68}$ See Ezeta, 62 F. at 999.

67 See Banoff \& Pyle, supra note 20, at 183 (noting that Ezeta's acts helped overthrow a previous political regime).

${ }_{68}$ See, e.g., Ornelas v. Ruiz, 161 U.S. 502, 510-12 (1896) (political offense exception applied to civilians who, as part of a group of 140 men, attacked 40 Mexican soldiers, killing some, burned, looted, and stole money and horses, and assaulted civilians); Banoff \& Pyle, supra note 20, at 184 ("Subsequent American cases have continued to apply the Ezeta-Castioni uprising test mechanically, whether or not the result is reasonable.").

170 F. Supp. 383 (S.D. Cal. 1959).

${ }^{70} \mathrm{Id}$. at 392-93.

71 See, e.g., Lubet \& Czackes, The Role of the American Judiciary in the Extra- 
The most severe criticism of the American judiciary's application of the political incidence test, however, has occurred as the result of recent cases dealing with international terrorists. ${ }^{72}$ In the first of these cases, In re McMullen, ${ }^{73}$ the magistrate refused to extradite a fugitive PIRA member for his bombing of a British army barracks in England. Similarly, in the case of In re Mackin, ${ }^{74}$ a court of appeals affirmed a magistrates refusal to extradite a PIRA member for allegedly killing a plain-clothes British policeman on a street corner in Belfast. ${ }^{75}$ And finally, in In re Doherty, ${ }^{76}$ a PIRA member was found to be nonextraditable because his alleged killing of a British army captain during an ambush was covered by the political offense exception. ${ }^{77}$

These decisions outraged the British government, which maintained that such refusals to extradite amounted to an American sanction of PIRA violence. ${ }^{78}$ But regardless of the result, those cases were properly decided under the provisions of the treaty.

Despite the decisions, in McMullen, Mackin, and Doherty, American courts have demonstrated an unwillingness to allow the political incidence test to shield all fugitive terrorists in the United States. In Eain v. Wilkes, ${ }^{7 \theta}$ the Seventh Circuit affirmed a federal magistrate's decision to certify for extradition a Palestinian accused of killing two Jewish children by placing a bomb in a crowded Israeli marketplace. ${ }^{\mathbf{8 0}}$ The court reasoned that Eain's action was not an offense of a political character because it was an indiscriminate bombing. ${ }^{81}$ While acknowledging that Eain's act had a political objective and was connected to an armed political struggle, ${ }^{82}$ the court concluded that the bombing was not "incidental" to the conflict. ${ }^{83}$ This subjective interpretation of the

dition of Political Terrorists, 71 J. CRIM. L. \& CRIMINology 193, 206-07 (1980).

72 See Hearings, supra note 2, at 4 (Statement of Judge Abraham Sofaer) (In expressing his displeasure regarding the judiciary's application of the political offense exception, Judge Sofaer queried "do we . . . want our country to serve as a sanctuary for terrorists who attack democratic governments?").

${ }_{73}$ Mag. No. 3-78-1099 M.G. (N.D. Cal. May 11, 1979), reprinted in 132

CoNG. REC. S9146 (daily ed. 1986).

74 668 F.2d 122 (2d Cir. 1981).

75 Id. at 137.

76599 F. Supp. 270 (S.D.N.Y. 1984).

77 Id. at 277.

${ }^{78}$ See Banoff \& Pyle, supra note 20 , at 185 . ("[T]he invocation of the uprising test was offensive to a most friendly nation and threatened to undermine Britain's willingness to surrender fugitives sought by the United States.").

${ }^{79} 641$ F.2d 504 (7th Cir.), cert. denied, 454 U.S. 894 (1981).

${ }^{80}$ Id. at 523-24.

81 See id. at 520-21.

${ }^{82}$ The court noted that the armed struggle of the PLO is to create a Palestinian homeland. See id. at 520 n.19.

s3 Id. at 520 . 
incidence test exposes the weakness of that test: in its strictest application, the test can be either overinclusive or underinclusive. For example, the test could exempt from extradition all crimes occurring during a political disturbance, but no offense that was not contemporaneous with an uprising. ${ }^{84}$ The Eain court tried to circumvent this problem by creating a "wanton crimes" exception to the political incidence test. Under this new exception, a fugitive could be extradited for killing civilians, even if the act satisfied the two-part incidence test. ${ }^{85}$ The problem with the "wanton crimes" exception, however, is that it complicates the political offense standard by allowing judges to make subjective judgments about foreign terrorist groups and their methods.

A more recent case demonstrating flexibility in the application of the political incidence test is Quinn v. Robinson. ${ }^{86}$ In Quinn, the fugitive being sought for extradition allegedly conspired to cause explosions in London and was also suspected of participating in the murder of a British police constable. ${ }^{87}$ The federal magistrate found Quinn extraditable but the district court reversed on appeal. ${ }^{88}$ The Ninth Circuit reinstated the magistrate's finding, holding that Quinn was not protected by the political offense exception. ${ }^{89}$ The Ninth Circuit rejected the Eain court's "wanton crimes" exception to the incidence test and adopted its own standard for determining extraditability. ${ }^{90}$ The Ninth Circuit explicitly rejected the notion that any "international terrorist" could claim the benefit of the political offense exception. ${ }^{91}$ The court held that because there was no "uprising" in England, Quinn's acts could not have been in furtherance of a political revolt. ${ }^{92}$ The court placed great emphasis on the principle that the term "uprising," for the purpose of the political incidence test, meant an uprising in the immediate geographic vicinity of where the act of violence occurred. In Quinn, the uprising was in Northern Ireland, not England, and there-

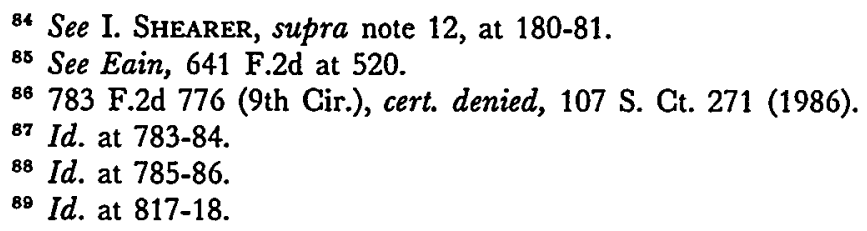

${ }^{80}$ See id. at 808 ("interpreting the political offense exception in light of its historic origins and goals"). For a more detailed discussion of the Quinn decision, see Note, $A$ Sewing Lesson in Political Offense Determinations: Stitching-Up the International Terrorist's Loophole, 10 Hastings INT'L \& CoMP. L. REv. 499, 513-20 (1987).

${ }^{91}$ See Quinn, 783 F.2d at 805 ("The desire to exclude international terrorists from the coverage of the political offense exception is a legitimate one . . . .").

${ }^{92}$ Id. at 806-08, 813. 
fore Quinn's act did not satisfy the first prong of the political incidence test. $^{\text {93 }}$

Although it claimed to be correctly applying the traditional incidence test, the Ninth Circuit's holding in Quinn demonstrates a departure from that test. Since Northern Ireland is governed directly from London, the capital of the United Kingdom, ${ }^{84}$ logic dictates that a group employing violence for political change would commit acts in that capital. The Quinn court appears to be guilty of the same subjective interpretation of the political incidence test as the Eain court, because it manipulated the test so as to exclude a particular group that it disfavored.

In addition to the somewhat inconsistent application of the political incidence test, United States courts have differed in adhering to the so-called "rule of non-inquiry." According to this rule, American courts should not examine the political motivations of the requesting government in extradition proceedings. The ${ }^{\circ}$ new Supplementary Treaty has modified both the political incidence test and the rule of non-inquiry.

\section{The Supplementary Treaty: Facial Concerns}

\section{A. Overview}

The Supplementary Treaty radically alters the role that federal magistrates and judges play in the extradition process. The heart of the Supplementary Treaty is article 1 . This article explicitly excludes a wide variety of crimes from the scope of the political offense exception. ${ }^{96}$ Subpart (a) of the article excludes from the category of political offense certain crimes listed in multinational conventions whose signatories include both the United States and the United Kingdom. These treaties in themselves do not exclude the operation of the political offense exception for the enumerated crimes. But now, under the Supplementary Treaty, a fugitive suspected of committing an offense in violation of the Convention for the Suppression of Unlawful Seizure of Aircraft, ${ }^{8 z}$ or the International Convention Against the Taking of Hos-

as See id. at 813 ("The magistrate correctly concluded that there was an uprising in Northern Ireland at the time of the offenses . . . . We cannot conclude, however, that the uprising extended to England.").

${ }^{24}$ Northern Ireland's Parliament was suspended in 1972. See id. at 812.

9s See Banoff \& Pyle, supra note 20, at 190.

${ }^{96}$ Supplementary Treaty, supra note 7 , art. 1. For further discussions of the scope of art. 1 see Blakesley, The Evisceration of the Political Offense Exception to Extradition, 15 DEN. J. INT'L L. \& Pol'y 109, 118-20 (1986); Note, supra note 46, at $778-82$.

97 Convention for the Suppression of the Unlawful Seizure of Aircraft, Dec. 16, 
tages, ${ }^{98}$ is barred automatically from the protection of the political offense exception, regardless of the political nature of the crime.

Subpart (b) excludes serious violent crimes against the person, including murder, voluntary manslaughter, and assault causing grievous bodily harm. ${ }^{99}$ Again, there is no distinction made for the offender whose acts are politically motivated.

Subparts (c), (d), and (e) exclude kidnapping, the taking of hostages, the use of any incendiary device, and participation as an accomplice in any article 1 act. ${ }^{100}$ Moreover, even the mere attempt to commit one of these acts precludes the exception. Article 1 in effect removes from judicial consideration the applicability of the political offense doctrine with regard to the nature of the act committed. ${ }^{101}$ The commission of almost any violent act, regardiess of motivation, will bar the invocation of the political offense exception.

\section{B. Criticisms of the Erosion of the Political Offense Exception}

Critics of this provision argue that the United States is in effect being enlisted by the United Kingdom as an ally in its internal struggle against the PIRA. ${ }^{102}$ As evidence of this charge, critics point out that there is currently no controversy between the United States and the United Kingdom regarding the extradition of terrorists to the United States. ${ }^{103}$ They argue that the interests of the United States are adequately protected by the existing treaty because no alleged U.S. terrorists have claimed the benefit of the political offense exception in U.K. courts. ${ }^{104}$ What this criticism overlooks, however, is the fact that both countries feel threatened by terrorism and believe that it is in their common interest to suppress it. ${ }^{108}$

1970, 22 U.S.T. 1641, T.I.A.S. No. 7192, 860 U.N.T.S. 105 (entered into force Oct. 14, 1971).

${ }_{88}$ Report of the Ad Hoc Committee on the Drafting of an International Convention Against the Taking of Hostages, G.A. Res. 34/146, 34 U.N. GAOR Supp. (No. 39) at 10, U.N. Doc. A/34/PV 105 (1980) (entered into force June 3, 1983) [hereinafter International Convention Against the Taking of Hostages].

29 Supplementary Treaty, supra note 7, art. 1(b).

100 Id. art. 1(c), (d).

101 Id.

102 See Hearings, supra note 2, at 281 (statement of Cherif Bassiouni) ("The purpose of the Supplementary Treaty is to assist Great Britain in quelling Irish Armed resistance. It is essentially an anti-IRA Treaty .....").

103 See id. at 282.

104 See id. at 281-82 ("[T]he Supplementary Treaty does not, on the basis of existing and past experience, benefit the U.S. . . ..").

${ }_{105}$ See id. at 2 (statement of Judge Abraham Sofaer) ("Terrorism . . . is rampant in the world today, and we are a favorite target. . . . This is a treaty that all Ameri- 
Another, perhaps more legitimate, criticism is that the Supplementary Treaty is overinclusive in that it exempts all violent acts from the protection of the political offense exception. ${ }^{106}$ Thus, not only are terrorists denied the benefit of the exception, but rebels who do not employ violence against civilians are also denied the exception. ${ }^{107}$ In other words, violent acts against civilians are put on the same level as attacks against police and military personnel. The treaty denies the legitimacy of violent opposition to the political status quo and forces political dissidents to fight for change through the existing political structure. Critics point out that many of the "Founding Fathers" of the United States employed violent tactics in their struggle against British colonial rule, and Article 1 of the Supplementary Treaty in effect delegitimizes their actions. ${ }^{108}$ Violence, it is urged, is sometimes a legitimate means to establish or reestablish certain moral, cultural, and religious values. ${ }^{109}$ The drawback of this criticism, however, is that it must reach far back in history to find its rationale. Both the United Kingdom and the United States were very different political entities during the revolutionary period than they are today. The two countries currently are among the most advanced democracies in the world, and it is difficult to imagine circumstances under which political violence in either country would need to be employed. It is by no means certain, however, that such circumstances will not occur sometime in the future. Moreover, the type of rebels who fought against British colonial rule 200 years ago were a far cry from many of today's international terrorists. ${ }^{110}$ Rather than fighting for traditional democratic values, today's terrorists are almost uniformly fighting to impose a totalitarian ideology on the

cans should enthusiastically support.").

${ }^{108}$ See id. at 228 (statement of Arthur Helton); id. at 231 (statement of David Carliner, Esq.).

107 See id. at 310 (statement of Charles Rice); see also Note, The Political Offense Exception: Is the United States-United Kingdom Supplementary Extradition Treaty the Beginning of the End?, 2 AM. U.J. INT'L L. \& POL'Y 203, 225-27 (1987) (arguing that article 1 sweeps too broadly and that only those terrorists committing "international" crimes should be denied the benefit of the political offense exception).

${ }^{108}$ See 132 Cong. Rec. S9161 (daily ed. July 16, 1986) (statement of Sen. Helms).

100 See id. at S9162.

110 See C. Sterling, The Terror Network 151-52 (1981); see also Hearings, supra note 2 , at 2 (statement of Judge Abraham Sofaer) ("They believe in bullets and bombs. We believe in rule by majority and they believe in rule by terror."); Baker, The Western European Legal Response to Terrorism, 13 BRoOKLYN J. INT'L. L. 1, 1 (1987) ("In describing himself as an evil spirit which moves around only at night causing constant nightmares, [the Palestinian Abu] Nidal personifies the reality of terrorism ...."); Friedlander, Terrorism and International Law: Recent Developments, 13 RuTGERS L.J. 493, 511 (1982). 
states within which they operate. ${ }^{111}$ Because the original purpose of the political offense exception was to protect democratic revolutionaries, it would seem contradictory to allow the exception to be used by those trying to destroy what those democrats created. ${ }^{112}$

Also associated with the overbreadth argument is the criticism that the traditional role of the judiciary in extradition has been usurped and the process has now become too politicized. ${ }^{113}$ Since there has been no agreement on a general definition of "political offense,"114 the reasoning goes, it is best left to the judiciary to make that determination on a case-by-case basis. Under the Supplementary Treaty, once a violent offense is committed, the extraditability of the accused will turn on the definition of "political offense" adopted by the incumbent executive administration. ${ }^{115}$ Whereas in the past the judiciary could establish criteria for determining the scope of the exception based on a concern for the accused, the executive can now make that decision on the basis of political expediency. ${ }^{116}$ Such a practice could subject the executive branch of government to criticism and possible embarrassment regarding its extradition policy. ${ }^{117}$

\section{Procedural Protections}

Despite the severe limitations that article 1 places on federal judges, article 3 of the Supplementary Treaty does allow the judiciary some discretion in certifying alleged political criminals for extradition.

111 See Hearings, supra note 2, at 2 (statement of Judge Abraham Sofaer); C. STERLING, supra note 110 , at 151; Baker, supra note 110 , at 10.

112 See I. Shearer, supra note 12, at 11-21; C. VAN DEN WyjGaerT, supra note 34 , at 9 . The modern concept of the political offense exception had its beginnings during the revolutionary period in Europe in the late eighteenth century. The French Republican Constitution, for example, had a provision granting asylum to individuals "banished from their countries for the cause of Freedom").

${ }_{113}$ See Note, supra note 30, at 641-43. But see Comment, The United StatesUnited Kingdom Supplementary Extradition Treaty: Limiting Availability of the "Political Crime" Defense, 9 Hous. J. INT'L L. 303, 328 (allowing the executive to make "the threshold decision that the requesting state is a democracy with an equitable legal system" is a positive development).

114 See id. at 637. For a more detailed discussion regarding the definitional problems of terrorism, see Baker, supra note 110, at 1-2; Bassiouni, Prolegomenon to Terror Violence, 12 CREIGHTON L. REV. 745, 751 (1979) ("[E]fforts to define terrorism have met with the resistance of those who, in the absence of a common basis of ideology, prefer the ambiguity of an undefined term.").

${ }_{115}$ See Hearings, supra note 2, at 315-16 (statement of Charles Rice).

116 See Lubet, supra note 30 , at $280-81$.

117 See id. at 285. ("The determination of the political offense issue by a neutral and judicial forum, however, actually might diminish the possibility of embarrassment to the government in the conduct of foreign affairs."). 
The first clause in article 3, the so-called "Aquino,"118 or "trumped up charge" clause, was inserted to prevent an otherwise innocent fugitive from being extradited simply because the requesting state had been able to make a showing of probable cause based upon false charges. ${ }^{119}$ The second clause asserts that even if legitimate probable cause is shown, extradition can be denied upon a finding that the accused will be prejudiced at her trial for the reasons stated in the article. ${ }^{120}$

The actual meaning of the second clause in article 3 has been a controversial issue, because it alters the traditional principle of noninquiry that prohibits the courts of the United States from examining the fairness of another country's legal system. ${ }^{121}$ One interpretation of the clause is that a fugitive could defeat extradition only if she proves that she "would" be prejudiced at trial, or punished, detained, or restricted in her personal liberty. ${ }^{\mathbf{1 2 2}}$ This interpretation would place a significant evidentiary burden on the fugitive. ${ }^{123}$ Senator Eagleton, ${ }^{124}$ for example, interprets article 3(a) as reflecting positively on the fairness of the criminal justice system in Northern Ireland. He believes that both countries would not have gone through the trouble of exempting certain serious crimes from the political offense exception, only to allow a federal court to defeat an extradition request by finding the system of criminal justice in Northern Ireland unfair. ${ }^{125}$ Senator Eagleton believes that article 3(a) is only a narrow limitation on article

118 Benigno Aquino, the former Phillippine opposition leader, was assassinated in 1983. See Marcos Foe Slain As He Goes Home From Exile In U.S., N.Y. Times, Aug. 22, 1983, at A1, col. 6. While Aquino was in exile in the U.S., the Phillippine government requested his extradition to face what were believed to be the false charges of plotting to cause explosions in Manila. See 132 CoNG. REC. S9253 (daily ed. July 17, 1986) (statement of Sen. Kerry) (referring to the "Ninoy Aquino test" as a means of avoiding extradition when the request is based on "trumped-up charges" or when the defendant cannot get a fair trial in the requesting state); Manila Reviving Charges Against Opposition Leader, N.Y. Times, Oct. 23, 1980, at 8A, col. 3.

119 See 132 Cong. Rec. S9167 (daily ed. July 16, 1986) (statement of Sen. Eagleton).

120 See id. at S9253 (daily ed. July 17, 1986) (statement of Sen. Kerry).

121 See id. at S9260-61 (statement of Sen. Biden); Banoff \& Pyle, supra note 20, at 188-90 (discussing the origin of the non-inquiry rule and its effects).

${ }_{122}$ See 132 Cong. Rec. S9167 (daily ed. July 16, 1986) (statement of Sen. Eagleton).

${ }^{223}$ See id.

124 Senator Eagleton has identified himself as the author of article 3(a). See id. In a later debate, Senator Eagleton demanded that the Senate take a hard line against all terrorists, asserting that " $[\mathrm{t}]$ hey are all terrorists; that is what they are. Terrorism is the same whether you have a swarthy complexion and talk in Arabic or whether you have pink cheeks and talk with a brogue." Id. S9252 (daily ed. July 17, 1986) (statement of Sen. Eagleton).

${ }^{125}$ See id. S9167 (daily ed. July 16, 1986) (statement of Sen. Eagleton). 
1, which allows a fugitive to defeat extradition only if she proves the charges against her are a sham or that she will be individually persecuted. ${ }^{128}$ The Senator also believes that article 3(a) leaves intact the rule of non-inquiry because a judge cannot pass judgment on the fairness of the foreign criminal justice system as a whole. ${ }^{127}$

The view taken by other members of the Senate Foreign Relations Committee would allow a judge's scrutiny of the fairness of the foreign judicial system and a denial of extradition if the judge found that the criminal process was fundamentally unfair. ${ }^{128}$ This interpretation of the Supplementary Treaty presents a problem because the fairness of the criminal justice system in Northern Ireland has been seriously questioned. ${ }^{129}$ Several pieces of emergency anti-terrorist legislation have been enacted in Northern Ireland, and some have extended to the United Kingdom as a whole. This legislation has curtailed severely the normal procedural safeguards given to criminal defendants. ${ }^{130}$ If this latter, more expansive view is adopted by federal judges, these judges will have to inquire into the criminal justice system of Northern Ireland once a fugitive presents evidence that she will not receive a fair trial. ${ }^{131}$

\section{The Supplementary Treaty: Problems of Application}

The Supplementary Treaty does not exist in a legal or political vacuum. Its practical effects will have serious consequences because of both what it says and what it does not say. Judges deciding on extradition requests may have to scrutinize closely the legal system in Northern Ireland. They may also have to contend with arguments that the Supplementary Treaty violates defendants' rights through its retroactive application. Meanwhile, the United States government will undoubtedly face requests for similar extradition arrangements from governments considered much less democratic than Great Britain's. This Part analyzes these problems, which are likely to arise in the application of the Supplementary Treaty.

${ }^{128}$ See id.

127 See id. In Senator Eagleton's view, "[a] court may not deny extradition because it concludes that a foreign tribunal does not provide every procedural safeguard provided by U.S. courts." Id.

${ }^{128}$ See id. at S9253 (daily ed. July 17, 1986) (statement of Sen. Kerry).

129 See id. (Sen. Kerry likening Northern Ireland's justice system to that of the Philippines under Ferdinand Marcos). For a more general discussion of European anti-terrorist legislation see Baker, supra note 110, at 10-22.

130 See infra notes $142-72$ and accompanying text.

131 But see supra note 127 and accompanying text. 


\section{A. The Northern Ireland Criminal Justice System}

It is important for federal judges to understand the many questionable practices inherent in the Northern Irish judicial system, because a fugitive may not get a fair trial in Northern Irish courts. In order to understand the current criminal justice process in Northern Ireland, it must be viewed in the context of the political situation in that province.

Northern Ireland is a part of the United Kingdom. It was created in 1921 after the British Parliament granted independence to twentysix of Ireland's thirty-two counties. ${ }^{132}$ The majority of the population in the six predominantly Protestant northern counties wanted to remain a part of the United Kingdom. Those six counties formed the basis of the new British province of Northern Ireland. ${ }^{\mathbf{1 3 3}}$ Since its inception, this entity has been controlled by a Protestant majority that has exercised power to the detriment of the Roman Catholic minority. ${ }^{\mathbf{1 3 4}}$ Protestant retaliation against Catholic civil rights activists resulted in the creation of a pro-Catholic paramilitary organization known as the Provisional IRA ("PIRA") in 1969. The PIRA was a splinter group from another organization known as the "Official IRA." The Official IRA advocated the withdrawal of Britain from Northern Ireland and the unification of the Province with the twenty-six-county Republic of Ireland. The split in the IRA resulted because the faction that became the PIRA advocated the use of force, while the other faction sought its goals through peaceful means. ${ }^{\text {135 }}$

The PIRA seeks to cause an atmosphere of such fear and violence in Northern Ireland that it will become impossible for Britain to govern that province. ${ }^{136}$ The PIRA hopes that the chaos it creates will precipitate a general uprising that will lead to the unification of Ireland.137

132 See J. Darby, Conflict in Northern Ireland 48-49 (1976); The Divided Province 6, 21 (K. Jeffery ed. 1985); R. Rose, Northern Ireland: Time of CHOICE 3 (1976).

${ }^{133}$ See The Divided Province, supta note 132, at 6, 20; M. Farrell, Northern Ireland: The Orange State 22 (2d ed. 1980); R. Rose, supra note 132 , at 3 .

134 See The Divided Province, supra note 132, at 23; R. Rose, supra note 132 , at $12-14$.

135 See W. Flackes, Northern Ireland: A Political Directory 163-66, 184-96 (1980); C. STERLING, supra note 110, at 152.

${ }^{136}$ See T. Coogan, The I.R.A. 470 (1980) ("The ultimate object of the campaign . . . [was] to render the existing state inoperable so that the army would have to withdraw."); The Divided PRovince, supra note 132, at 50 (stating the PIRA objective of forcing British withdrawal by armed action); C. STERLING, supra note 110, at 162-63 (discussing the PIRA goal of general suffering as a prelude to change).

137 See C. STERLING, supra note 110 , at 162. 
The strategy of the PIRA has included the bombing of civilians ${ }^{\mathbf{1 3 8}}$ as well as attacks upon the Northern Ireland security forces. ${ }^{139}$

Faced with rising violence from the PIRA as well as other extremist, pro-unionist paramilitary groups, ${ }^{140}$ the British government dissolved the Northern Irish Parliament in 1972 and ruled the province directly from London. ${ }^{141}$ Along with imposing this direct rule, the British Parliament enacted several pieces of legislation that radically altered the criminal justice system in Northern Ireland in an effort to better combat terrorism there. The two laws that most significantly affect the rights of the accused in terrorist cases are the Northern Ireland (Emergency Provisions) Act of 1978 ("EPA") 142 and the Prevention of Terrorism (Temporary Provisions) Act of 1984 ("PTA"). ${ }^{143}$

The EPA consolidates several earlier statutes that were enacted pursuant to a 1972 report to the British government on security problems in Northern Ireland. This report recommended that the Province's legal system be altered in order to deal better with increasing terrorist activity. ${ }^{144}$ The EPA applies only to Northern Ireland. ${ }^{145}$ The PTA, also enacted to combat terrorism, applies throughout the entire United Kingdom. ${ }^{146}$ The EPA must be reviewed by the British Parlia-

${ }^{138}$ See T. Coogan, supra note 136, at $478-79$ (Statistical study reported 1341 civilian deaths as of 1980 from political violence in Northern Ireland.); THE DIvideD Province, supra note 132, at 56, 73 (theory behind bombings); C. STERLING, supra note 110, at 164-65, 298 (examples of PIRA bomb attacks on civilians); see also In re Doherty, 599 F. Supp. 270, 273 (S.D.N.Y. 1984) (PIRA and loyalist violence "between 1972 and 1979 claimed the lives of over 1,770 persons, nearly 1,300 of whom were civilian casualties and injured hundreds of others.").

199 See, e.g., Quinn v. Robinson, 783 F.2d 776, 783-85 (9th Cir. 1986) (describing six PIRA letter-bomb attacks on officials in England); In re Mackin, 668 F.2d 122, 124 (2d Cir. 1981) (considering extradition of PIRA members who had entered the United States illegally while on bail on charges of the attempted murder of a British soldier); Doherty, 599 F. Supp. at 272 (S.D.N.Y. 1984) (considering extradition of PIRA member who admitted ambushing British troops and killing a soldier); M. FARRELL, supra note 133, at 279 (describing an example of the "conventional military action" that took place).

140 See, K. Boyle, T. Hadden \& P. Hill.yard, Ten Years On In Northern IrELAND 19-22 (1980); W. FlaCKes, supra note 135, at 229-33, 242-45 (discussing violent activity of the Unionist Ulster Defense Association and Ulster Volunteer Force).

141 See Quinn, 783 F.2d at 812; J. DARBY, supra note 132, at 25; R. ROSE, supra note 132 , at 27.

142 Northern Ireland (Emergency Provisions) Act, 1978, ch. 5. The first version of the EPA was enacted in 1973. Northern Ireland (Emergency Provisions) Act, 1973, ch. 53.

143 Prevention of Terrorism (Temporary Provisions) Act, 1984, ch. 8.

144 See Report of the Commission to Consider Legal Procedures to Deal with Terrorist Activities in Northern Ireland, 1972, Cmnd. Ser. 5, No. 5185 (Lord Diplock, Ghairman) [hereinafter DiPlock REPORT].

${ }_{148}$ See Emergency Provisions Act, 1978, Preliminary Note.

148 See Prevention of Terrorism Act, Preliminary Note. 
ment every six months, ${ }^{147}$ and the PTA must be reviewed every twelve months. ${ }^{148}$

The EPA makes membership in certain paramilitary organizations a crime. ${ }^{149}$ In addition, merely behaving in public "like a member of a proscribed organization" carries a criminal penalty. ${ }^{150}$ Moreover, the EPA outlaws the gathering of information that might be useful to terrorist groups regarding individual police officers, soldiers, judges, and prison employees. It also outlaws training other persons in the use of firearms and explosives. ${ }^{181}$ The EPA places limits upon an individual's freedom of speech. It prohibits solicitation of support for proscribed organizations $\mathrm{s}^{\mathbf{1 6 2}}$ and it gives the security forces the power to disperse assemblies. ${ }^{153}$ The PTA does not deal with matters of speech and assembly. The PTA creates crimes similar to those in the EPA, except that the proscriptions in the PTA apply throughout the entire United Kingdom. ${ }^{154}$

Both acts give the police extensive authority to detain suspected terrorists without charge for long periods of time. The EPA allows a "constable," defined as a member of either civilian or military police, ${ }^{155}$ to arrest any person "suspect[ed] of being a terrorist" and to hold that person for up to seventy-two hours. ${ }^{158}$ In addition, the military can arrest a person upon mere suspicion and hold her for an unspecified period. ${ }^{157}$ The PTA allows the police to exercise broad powers of arrest anywhere in the United Kingdom. It allows the police to arrest anyone they have "reasonable grounds" to suspect of being "concerned in the commission, preparation or instigation of acts of terrorism" connected with Northern Ireland, and to hold that person for up to forty-eight hours. ${ }^{158}$

Both acts allow the police and the army to conduct broad-ranging

${ }^{147}$ Emergency Provisions Act, § 33.

148 Prevention of Terrorism Act, $\S 17$.

149 Emergency Provisions Act, $\S 21 \&$ Sched. 2. In addition to the Irish Republican Army and several more obscure Nationalist Catholic organizations, the proscribed groups include the Unionist (Protestant) Red Hand Commando, Ulster Freedom Fighters, and Ulster Volunteer Force. Id.

${ }^{150} I d$. $\& 36(2)$.

151 Id. \& 25.

162 Id. $\S 21$.

${ }^{163}$ Id. $\$ 24$.

164 Prevention of Terrorism Act, $\S 12$.

${ }_{155}$ Emergency Provisions Act, $\S 11$ \& notes.

${ }^{158}$ Id.

${ }^{157}$ Id. $\S 14$. The Diplock Report recommended that police be given the authority to detain any person on suspicion "for a period of not more than four hours for the purpose of establishing his identity." DIPLOCK REPORT, supra note 144, at 21 .

158 Prevention of Terrorism Act, $\S 12$. The PTA definition of "constable" omits reference to the Royal Naval, Military, and Air Force Police. Id. $\S 2 \&$ notes. 
searches. Under the EPA, officials can enter "any premises or other place other than a dwelling house" to search for munitions or transmitters. This authority is subject only to the limitation that the officials must have "suspicion" before they can conduct such a search. ${ }^{159}$ The security forces may also enter any premises when necessary "for the preservation of the peace or the maintenance of order."160

Under the PTA, however, the power of the authorities to search and seize is much more limited. The Secretary of State for Northern Ireland must give authorization to officials before they may board seagoing vessels to determine whether persons entering or leaving the United Kingdom have been involved in the commission, preparation, or instigation of an act of terrorism. ${ }^{\mathbf{1 6 1}}$

The EPA extends the authority of officials to detain suspected terrorists before trial. The "EPA removes the power to grant bail from magistrates and justices of the peace and makes it available only upon application to a High Court judge."162 Threats, intimidation, and actual violence against court officers necessitated this reform. ${ }^{163}$ The EPA also shifts to the accused the burden of satisfying the high court judge that he has met the requirements for bail. In England, the burden is ordinarily on the prosecution. ${ }^{\mathbf{1 6 4}}$

The EPA eliminates the right to a jury trial for those charged with committing enumerated terrorist offenses. ${ }^{165}$ Under the EPA, suspected terrorists are tried by so-called "Diplock" courts. These courts are named after the British Lord Diplock, who, in a 1972 report, recommended that a special type of criminal court be created in order to better combat terrorism. ${ }^{168} \mathrm{~A}$ trial is potentially within the jurisdiction of the Diplock courts if any charge against the defendant is one of a specified set of common law offenses characteristic of terrorism and listed in the EPA. ${ }^{167}$ Such offenses include murder, kidnapping, assault, conspiracy, crimes involving firearms or explosives, arson, and aggravated burglary. ${ }^{168}$

158 Emergency Provisions Act, § 15(I).

160 Id. $\S 19$.

101 Prevention of Terrorism Act, $\S \S 13(1)(\mathrm{a})(\mathrm{i}),(2)(\mathrm{b})$.

162 Emergency Provisions Act, $\S 12$; see Hearings, supra note 2, at 558 (responses of Judge Abraham Sofaer to questions from Sen. Dodd).

${ }^{163}$ See Diplock REPORT, supra note 144, at 14-16.

104 See id. at 23-24.

165 Emergency Provisions Act, $\S 7(1$ ) (a trial on "indictment of a scheduled offense shall be conducted by a court without a jury"); see DIPLOCK REPORT, supra note 144 , at $40-42$ (recommending use of trial without a jury for listed schedule of offenses).

${ }^{168}$ See Diplock RePort, supra note 144 , at 17-19.

167 Emergency Provisions Act, \& 30 \& Sched. 4.

${ }^{168}$ Id. 
The British government created this regime in the belief that the jury system in Northern Ireland "was in danger of a complete breakdown."169 Reports of terrorists intimidating juries and threatening retaliation for "bad" jury verdicts spurred Parliament to revamp the manner in which the criminal justice system processed suspected terrorists. Whether or not these reports were true, the perception of their truth may have been sufficient to prompt passage of the law. As Lord Diplock observed, a "frightened juror is a bad juror even though his own safety and that of his family may not actually be at risk."170 Moreover, there was a concern that the verdicts that juries delivered were often determined by the politics and religion of the accused. For example, Protestant juries tended to convict IRA defendants at a much higher rate than they convict Unionist defendants. ${ }^{171}$

Despite the lack of a jury, the Diplock system provides several procedural safeguards. The judge in a Diplock court must state the basis for her verdict in writing. Her findings of both fact and law can be reviewed on appeal. ${ }^{172}$ The result of such safeguards has been that acquittal rates for defendants in Diplock courts tend to be about the same as for those in ordinary criminal trials in Northern Ireland. ${ }^{173}$

In Northern Ireland, unlike in England, an application for legal aid must be granted unless the defendant is found to have sufficient financial means to obtain her own counsel. In England, a defendant is only guaranteed counsel when she is accused of murder or when the prosecution takes an appeal. ${ }^{174}$

In addition to criticisms of its criminal process, Britain has also come under fire for its officials' treatment of suspects and convicts in their custody. In 1971, the government of the Republic of Ireland filed a complaint with the European Commission on Human Rights alleging that the British had violated article 3 of the European Convention on Human Rights. The complaint alleged that British authorities brutalized subjected pretrial detainees during interrogation. ${ }^{175}$ In 1978 , the

${ }^{169} 132$ CONG. REC. S9170 (daily ed. July 16, 1986) (statement of Sen. Lugar) (incorporating analysis of Diplock courts prepared by the State Department).

${ }_{170}$ Diplock REPORT, supra note 144, at 17.

171 See id. at 18 .

172 Emergency Provisions Act, § 7(5), (6); see Diplock REPORT, supra note 144,

173 In $1984,53 \%$ of all nonjury trials ended with the acquittal of the defendant. See Hearings, supra note 2, at 13 (testimony of Judge Abraham Sofaer).

174 See Hearings, supra note 2, at 558-59 (responses of Judge Abraham Sofaer to questions from Sen. Dodd).

${ }_{175}$ See European Convention for the Protection of Human Rights and Fundamental Freedoms, Nov. 4, 1950, no. 2889, 213 U.N.T.S. 221. Article III provides: "No one shall be subjected to torture or to inhuman or degrading treatment or punishment." Id., art. III. 
European Court of Human Rights found that the techniques constituted inhuman and degrading treatment, but not torture. ${ }^{\mathbf{1 7 6}}$

In 1977, Amnesty International investigated complaints that suspects were being mistreated while in the custody of the Royal Ulster Constabulary ("RUC"), the Northern Ireland police force. ${ }^{177}$ The British responded to the investigation by establishing a commission that eventually recommended changes in the interrogation methods used by the RUC. ${ }^{178}$

These facts about the criminal justice system in Northern Ireland raise questions as to whether that system is fair enough to allow the United States to return fugitives and have confidence that those fugitives will be treated justly. ${ }^{179}$ In order to determine the reasonableness and fairness of the Northern Irish judicial system, judges should balance the limited rights suspects enjoy under the EPA and the PTA against the role that terrorist violence has played in altering Northern Irish judicial procedures. ${ }^{180}$ Superficially, it is easy to look from a distance and criticize other countries for not adhering to the high standards of justice to which Western countries have grown accustomed. The United Kingdom, however, is faced with a serious threat to its internal security and believes that only extraordinary measures will remedy that threat. Moreover, more than simply the future of Northern Ireland is at stake. The PIRA has also declared war on the Republic of Ireland and has made no secret of its desire to topple that democracy and replace it with a less democratic regime. ${ }^{\mathbf{1 8 1}}$ Interestingly enough, the Republic of Ireland also employs special juryless courts to try sus-

${ }^{176}$ See Ireland v. United Kingdom, 25 Eur. Ct. H.R. (ser. A) 66-67 (1978) (five interrogation techniques used by British violated article III).

177 See AMNESTY INTERNATIONAL, Report OF AN AMNESTY INTERNATIONAL Mission to Northern IRELAND (28 NOveMBER-6 December 1977) 2-4 (1978).

178 See RePORT OF THE COMMITTEe of INQUIRY INTO POLICE INTERROGation Procedures in Northern Ireland, 1979 CMND. Ser. 5, No. 7497, at 135-40 (recommending, inter alia, development of a code of conduct for interviewers, increased involvement of medical officers in supervision of detainees, and increased access to solicitors during detention).

178 See supra notes $10,118-31$ and accompanying text.

${ }^{180}$ Cf. Hearings, supra note 2, at 18 (statement of Judge Abraham Sofaer) (commenting on the Diplock courts, that if the United States "had the kind of problem that they have in Northern Ireland, [the U.S.] would be doing pretty well [to have] a system as fair as the one they have").

181 See C. STERling, supra note 110, at 157 ("Victory in the north means not just defeat of the [Protestant] Loyalists and the unity of Ireland, but also the collapse of the government in the south and an anti-imperialist revolution in that country." (quoting Michael Farrell, Irish revolutionary, from O. DEMaRIs, L'INTERNATIONALE TERRORISTE 365-66, 370 (1978))); see also O'Brien, Irish Terrorists and Extradition: The Tuite Case, 18 TEx. INT'L L.J. 249, 254 n.22 (1983) (IRA advocates overthrow of the Republic of Ireland); Comment, supra note 113, at 324 (IRA advocates unification of the "entire island."). 
pected terrorists. ${ }^{182}$ Thus, the Diplock courts are not merely a British weapon against Irish nationalism.

Judge Sprizzo, in In re Doherty, ${ }^{\mathbf{1 8 3}}$ commented upon the fairness of the British Diplock court system in Northern Ireland. ${ }^{184}$ He specifically rejected the charge that the Diplock courts and the procedures they employ are inherently unfair. ${ }^{185}$ Judge Sprizzo concluded "that both Unionists and Republicans who commit offenses of a political character can and do receive fair and impartial justice." ${ }^{\text {"88 }}$ Although he violated the rule of non-inquiry, ${ }^{187}$ Judge Sprizzo's assertion made it easier for senators opposed to the inclusion of article 3(a) in the Supplementary Treaty to accept that provision because it indicated that, under the standard set forth in 3(a), the Northern Irish judicial system was fair. ${ }^{188}$ It seemed hardly logical to enter into a new treaty that allowed extradition by altering radically the scope of the political offense exception only to allow judges to deny extradition based upon the unfairness of the Northern Irish judicial system.

The Committee on Foreign Relations took special note of Judge Sprizzo's dictum on the Diplock courts in its evaluation of the new treaty ${ }^{189}$ Some in Congress, however, believe that his was not the last word on that subject. ${ }^{\mathbf{1 9 0}}$ Judge Sprizzo, it is claimed, based his decision upon the testimonial evidence of United States government witnesses who were acting on behalf of the British government during Doherty's extradition hearing. ${ }^{101}$ The defendant, Doherty, did not and probably could not have introduced any evidence to refute the government's facts. ${ }^{102}$ Under the new treaty, fugitives will be allowed to introduce evidence in order to establish the unfairness of the judicial system to which they are being returned. Consequently, another federal judge de-

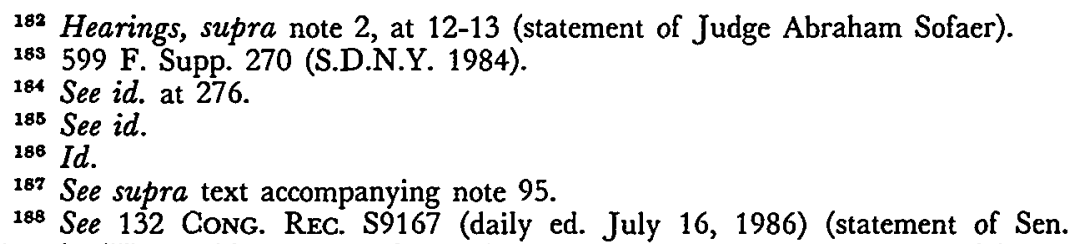
Eagleton) ("I consider Judge Sprizzo's opinion, as it relates to the fairness of the Diplock court system, as being conformative to our intent in fashioning article 3(a) .....").

180 See id. at S9254 (daily ed. July 17, 1986) (statement of Sen. Kerry) (reporting the Committee's concern that fugitives sought for extradition have an opportunity to challenge the fairness of the judicial system that would try them).

100 See id. (statement of Sen. Kerry) (noting first, that Judge Sprizzo's assessment was based on one-sided testimony without provision for rebuttal, and second, that Judge Sprizzo had no authority under existing law to investigate Northern Ireland's justice system).

191 See id.

102 See id. 
termining Doherty's extraditability under the Supplementary Treaty might reach a conclusion different from that of Judge Sprizzo, based upon evidence submitted by the fugitive.

\section{B. Retroactivity}

An important effect of the Supplementary Treaty is its retroactive operation upon fugitives previously sought for extradition. ${ }^{193}$ Proponents of the retroactivity clause see no unfairness in further attempts to return a fugitive whose extradition was denied under the political offense exception in an earlier proceeding. ${ }^{194}$ Their rationale is that the acts committed by the fugitive are already criminal, so the retroactivity clause would not impose any new punishment or create any new crime. ${ }^{195}$ Rather, the Supplementary Treaty, in conformity with other American extradition treaties, simply grants the requesting state another opportunity to obtain the return of one of its nationals.

Those opposed to the retroactivity clause point out that it has an effect similar to that of a bill of attainder or an ex post facto law. ${ }^{198}$ If no new crime or punishment is involved, however, this criticism appears to be groundless. Indeed, the United States currently has twentyone extradition treaties with retroactivity clauses. ${ }^{\mathbf{1 9 z}}$

A more pertinent objection is the lack of a res judicata effect arising from extradition proceedings; however, there is no provision in United States extradition law requiring the application of res judicata to extradition proceedings. ${ }^{198}$ The Office of the Legal Adviser of the

${ }^{183}$ See Supplementary Treaty, supra note 7, art. 5 (general retroactive application of the treaty).

194 See 132 Cong. Rec. S9156 (daily ed. July 16, 1986) (statement of Sen. Lugar) (resisting the amendment, proposed by Senator D'Amato, that would bar retroactive application of the Supplementary Treaty when extradition had been sought and denied in a United States court).

195 See id. at S9154 (statement of Sen. Lugar) (noting that murder and attempted murder are each proscribed by both the United States and the United Kingdom).

186 See id. at S9153 (statement of Sen. D'Amato) (objecting to the retroactive eradication of the political offense exception and citing U.S. Const. art. I, $\S 9, \mathrm{cl} .3$ (the bill of attainder/ex post facto clause)).

107 See id. at S9158 (reprinting a letter from Mary V. Mochary, Deputy Legal Adviser of the United States Department of State, listing Austria, Iceland, Belguim, Latvia, Bulgaria, Lithuania, Congo (Bazzaville), Luxembourg, Cuba, Poland, Czechoslovakia, Rumania, Ecuador, San Marino, Estonia, France, Sweden, Switzerland, Guatemala, the United Kingdom, and Honduras as having retroactive supplementary extradition treaties with the United States).

198 See In re Mackin, 668 F.2d 122, 128 (2d Cir. 1981); Hooker v. Klein, 573 F.2d 1360, 1368 (9th Cir.), cert. denied, 439 U.S. 932 (1978); Comment, The Turning Point Approaches: The Political Offense Exception to Extradition, 24 SAN Diego L. REv. 549, 553 (1987); see also Note, supra note 46, at 766 n.50 (noting that Yugoslavia has taken advantage of the fact that an extradition proceeding is not accorded res 
Department of State has said that United States policy will be to extradite those fugitives previously given the benefit of the political offense exception. ${ }^{199}$ Double jeopardy will not be an issue in the new proceeding because that fifth amendment right does not attach until the trial has actually begun. ${ }^{200}$ Thus, because an extradition hearing is more like a pretrial proceeding than a trial, the fugitive is not being tried twice. $^{201}$

If the United Kingdom were again to request the extradition of McMullen, Mackin, and Doherty, federal courts would have to reevaluate their status under the terms of the Supplementary Treaty. All three fugitives committed acts of violence against officers of the requesting state and would therefore be automatically barred from invoking the political offense exception under article 1 of the Supplementary Treaty. A court could declare one of the three nonextraditable only if they found the fugitive nonextraditable under article 3(a). Ironically, such a conclusion would probably outrage the British more than did the decision not to extradite the three PIRA fugitives under the political offense exception.

\section{Double Standard}

Another problem created by the Supplementary Treaty-which will become even more pronounced if the United States concludes similar treaties with other liberal democracies ${ }^{202}$-is that it compels the use

judicata effect).

190 See Hearings, supra note 2, at 569 app. (responses of Judge Abraham Sofaer to questions from Sen. Biden) (noting that the U.S. is appealing to reverse the denials of Quinn and Doherty's extradition). Judge Sofaer's response renders the Administration's position somewhat perplexing with respect to Quinn and Doherty since a denial of extradition was held to be not appealable in Mackin. See Mackin, 668 F.2d at 12530.

${ }^{200}$ See Hooker, 573 F.2d at 1367 n.7; 132 Cong. REc. S9158 (daily ed. June 23, 1986) (letter from Mary V. Mochary, Deputy Legal Adviser, Department of State).

${ }_{201}$ See Hooker, 573 F.2d at 1367 ("A finding of extradition . . . is truly an interlocutory order, more akin to a preliminary hearing on criminal charges [than to a final judgment.]"); 18 U.S.C. $§ 3184$ (1982) (The court's determination in extradition proceedings is only whether the evidence presented is "sufficient to sustain the charge under the provisions of the proper treaty or convention . . ..").

${ }^{202}$ At the time of the completion of this Comment, the United States had just enacted Supplementary Treaties with Belgium, signed at Washington, Mar. 17, 1987, and the Federal Republic of Germany, signed Oct. 21, 1986. See Hearings, supra note 2 , at 20 (statement of Judge Abraham Sofaer) (alluding to the negotiation of these treaties).

For a more detailed discussion of the problems of adjusting extradition treaties on a country-by-country basis, see Comment, supra note 198, at 564-66, which argues that the treaty-by-treaty approach is "unwise," in part because it cannot avoid commenting implicitly on the presumed fairness of a country's judicial system. The Comment also proposes criteria for defining "political" crimes and disapproves of the usur- 
of a double standard in United States extradition practice. In the United Kingdom and other western liberal democracies, all violent crime, regardless of motive, will bar the invocation of the political offense exception. The United States, by concluding this type of treaty with such countries, places its imprimatur on the political and legal status quo in those countries. Conversely, the United States will be implying that it does not have confidence in the political and legal status quo in nations with which it does not conclude similar treaties. Such diverse treatment may cause America's nondemocratic allies to exert pressure for the execution of similar treaties limiting the scope of the political offense exception. These countries could conceivably use a new treaty as a precondition for the use of military bases by American forces, but submission to their demands could signal the end of the political offense exception even for democratic rebels. Despite this troublesome double standard, the present United States Administration insists that it will not be pressured into concluding similar treaties with nondemocratic states. Abraham Sofaer, the State Department Legal Adviser, insisted during the Senate hearings on the Supplementary Treaty that new treaties with limited political offense exception provisions would not be concluded with countries that have "no open system of political opposition and dissent," or "where the system of justice is fundamentally unfair."203 Nevertheless, there are those who believe that the Administration is planning to, and should, conclude similar treaties with all American allies, regardless of their political color. ${ }^{204}$

One incident lending credibility to critics is the Reagan Administration's attempt to negotiate a new extradition treaty with the Philippines in 1981. Despite his imposition of ten years of martial law ${ }^{205}$ and

pation of the power of the judiciary in extradition proceedings. See id. at 567-72; see also Hearings, supra note 2, at 104-06 (statement of Prof. Christopher Pyle) (advocating judicial retention of decisionmaking authority with respect to the political nature of crimes, and arguing against the double standard applied to "political refugees" through analysis of their countries legal systems). For an analysis of how Western European governments have dealt with the problem of extraditing alleged terrorists see Baker, supra note 110 . Baker, while noting that its effectiveness has been criticized, concludes that the European Convention on the Suppression of Terrorism is a viable regional tool for combating terrorism. See id. at 5.

${ }^{203}$ Hearings, supra note 2, at 20 (statement of Judge Abraham Sofaer).

${ }^{204}$ See Lauter, U.S., Britain Sign New Pact on Fugitives, NAT'L L.J., July 29, 1985, at 5 (quoting Stephen Trott, Assistant Attorney General). A third position is that the Administration will be selective with respect to its eradication of the political offense exception, but that the selection will be based on subjective political leanings and the preferences of the Administration, rather than on a principled analysis of the fairness of a foreign legal system. See id. at 33 (quoting former Attorney General Ramsey Glark's statement implying that the Administration wants to accommodate Britain but not, for example, Nicaragua, regardless of fairness of process).

${ }_{20 s}$ See Hearings, supra note 2, at 119 (statement of Prof. Christopher Pyle) (not- 
his government's appalling human rights record, ${ }^{208}$ former Philippine dictator Ferdinand Marcos was offered aid by the Reagan Administration in obtaining the extradition of his enemies from the United States. One of those enemies was Senator Benigno Aquino, Marcos's main political rival, then in exile in the United States. ${ }^{207}$ The extradition treaty under negotiation at that time would have limited the political offense exception in a manner similar to that of the Supplementary Treaty discussed in this Comment. ${ }^{208}$ After the treaty was signed on November 27, 1981, Marcos obtained arrest warrants for some forty Philippine exiles-including Senator Aquino-who were accused of "seditious" and "subversive" activities against the Marcos regime. ${ }^{208}$ The public outcry against Marcos's tactics was so great, however, that the State Department never submitted the treaty to the Senate for its required consent. ${ }^{210}$ Throughout this episode, the Reagan Administration continued to praise the Marcos regime as "democratic" and to call Marcos himself a "voice for reason and moderation," 211 indicating that this Administration defines "democratic" very loosely when claiming that it will limit supplementary treaties to democratic allies. Although the Philippines has a new, more progressive government, other American allies with less-than-distinguished human rights records, such as South Africa and South Korea, could also be eager for a new treaty.

\section{A Proposal}

The Supplementary Treaty is open to criticism because of its retroactivity, and because of the double standard it creates. What is perhaps most objectionable, however, is the Supplemental Treaty's broad sweep in removing offenders from the protection of the political offense exception. ${ }^{212}$

A preferable solution might have been the negotiation by the United States and the United Kingdom of a treaty defining "political offense" by whether the violent act was directed against officers of the

ing that martial law was in effect from 1972-1981).

${ }^{206}$ See id. (citing the findings of the International League for Human Rights and of Amnesty International that thousands were "detained on suspicion of subversive activity" and that "many of those jailed were brutalized or tortured by their interrogators," frequently without having been convicted of any crime).

${ }^{207}$ See id. at 119-20.

${ }^{208}$ See id. at 120 (The treaty "proposed transferring administration of the political crimes defense from the judiciary to the State Department.").

${ }^{209}$ See id. Aquino's voluntary return to the Philippines ended in his assassination on August 21, 1983. See supra note 118 and accompanying text.

${ }_{210}$ See Hearings, supra note 2, at 120 (statement of Prof. Christopher Pyle).

211 Id. at 122.

${ }^{212}$ See supra notes 106-09 and accompanying text. 
state, or against civilians. By categorically denying the exception to those who attacked civilians, such a treaty would allow the punishment of the most offensive type of terrorist acts. Both the Eain ${ }^{213}$ and Quinn ${ }^{214}$ courts seemed to follow this line of reasoning when they denied the exception to fugitives who attacked civilians. The community's sense of outrage is far greater when civilians are attacked because such violence is usually arbitrary and does not directly harm the state. Attacks against police officers and soldiers, however, are more obviously attacks against the state and seem covered by the traditional notion of a political offense. Even this solution is unsatisfactory, however, for the real issue is not who the victim is but whether the alleged offender can get a fair trial in, the requesting state. It is the conflict between the right to a fair trial and the need to punish terrorists that must be resolved.

It is highly doubtful that an alleged political offender can get a fair trial in the requesting state, for her crimes were committed against the very institutions determining her guilt or innocence. A better alternative is to have a third party make that determination. The European Community, for example, could establish a special criminal court to try alleged terrorists from the Community's member states. Since many of the Community's members suffer from terrorist violence, they would have an incentive to see that such a court operates successfully.

Under this scheme, each of the member states would contribute judges, prosecutors, and other court personnel to the system. When an alleged political offender is on trial, under no circumstances could the judge be of the same nationality as the accused. This would better ensure a fair trial for the accused and protect the interests of the injured state in seeing that justice is done. Such a system would also help the United States avoid the dilemma it currently faces with respect to the extradition of terrorists. By returning the accused to an impartial European court, the United States would avoid having to decide between returning a fugitive to a state where she may not get a fair trial, or offending that state by not returning the fugitive at all.

Under the proposed scheme, the fugitive being sought for extradition would have to petition the special terrorist court to obtain its protection. In order to invoke its jurisdiction, the court would have to determine if the fugitive had made at least a prima facie showing that the offense she was accused of committing was politically motivated. If the fugitive made such a showing, the court could make an extradition re-

${ }^{213}$ Eain v. Wilkes, 641 F.2d 504 (7th Cir.), cert. denied, 454 U.S. 894 (1981). (1986).

214 Quinn v. Robinson, 783 F.2d 776 (9th Cir.), cert. denied, 107 S. Ct. 271 
quest to the country holding the fugitive. The special court would then try the fugitive under the regular procedural and substantive criminal law of the offended state. Alternatively, the European Community could formulate its own body of procedures as well as its own criminal code, to which provisions the Community's states would assent by treaty.

There is an important precedent in the area of European interstate cooperation that could serve as a model for the proposed court. That model is the European Court of Human Rights, which was established pursuant to the European Convention on Human Rights. This court has found several Community states, including the United Kingdom, guilty of human rights violations. ${ }^{215}$ Indeed, the judicial machinery established pursuant to the European Convention on Human Rights is considered the most advanced and effective system for the protection of human rights in the world. ${ }^{216}$

Under the European Convention on Human Rights, states, or individuals, if they have exhausted all legal remedies in their national legal systems, can petition the European Commission if they believe that a signatory state has violated the European Convention. ${ }^{217}$ After investigating the factual averments in the complaint, the Commission then attempts to facilitate a settlement between the parties. ${ }^{218}$ If no settlement is reached, the Commission draws up a report stating whether or not the defendant state has violated the Convention. ${ }^{219}$ Within three months of the issuance of the report, the Commission, or any of the parties involved in the dispute, can take the case to the European Court of Human Rights. ${ }^{220}$ In cases in which the Court has found violations of the Convention, states have taken remedial action to correct their behavior. For example, after the Golder Case, ${ }^{221}$ the British government changed its prison regulations in order to eliminate the practice of allowing prison authorities to control communications between a prisoner and her lawyer. ${ }^{222}$ Similarly, even before the Court's decision in Ireland v. United Kingdom, ${ }^{223}$ Britain ceased to employ the so-called

215 See supra note 176.

${ }^{218}$ For a detailed description of the Convention see Higgins, The European Convention on Human Rights, in 2 Human Rights IN INTERNaTIONAL LAW: LEGaL. AND Policy Issues 495 (T. Meron ed. 1984).

217 See id. at 505-06.

218 See id. at 506.

219 See id. at 506-07.

220 See id. at 507.

${ }^{221} 1975$ Y.B. Eur. Conv. ON HuM. RTs. 290 (Eur. Comm'n on Hum. Rts.).

222 See Higgins, supra note 216, at 509.

223 Eur. Ct. H.R. (ser. A) (1978). 
"five interrogation techniques."224

\section{Conclusion}

The new United States-United Kingdom Supplementary Extradition Treaty appears to represent an effective means by which two democratic allies can prevent those accused of committing violent acts for political purposes from escaping justice. Moreover, the treaty provides a safeguard for the accused by denying extradition if the evidence against the fugitive is incredible or if she would not receive a fair trial upon her return.

The problem with this new treaty is that, although it remedies certain problems that existed under the old regime, it still does not resolve adequately the problem of how to deal fairly with alleged political offenders. Article 1, for example, sweeps too broadly in its denial of the political offense exception to those who commit acts of political violence. It ignores the possibility that there may be some circumstances under which a person committing such an act deserves protection.

Unless the liberal democracies establish a system whereby an alleged fugitive terrorist would be tried by an impartial third party such as the European Community, the United States should not negotiate treaties with other allies eliminating the political offense exception for all violent crimes. Rather, if the exception is to be limited at all, it should be denied to those who commit acts of violence against civilians. 
